This article was downloaded by: [University of Sydney]

On: 04 May 2015, At: 08:38

Publisher: Routledge

Informa Ltd Registered in England and Wales Registered Number: 1072954

Registered office: Mortimer House, 37-41 Mortimer Street, London W1T

3J H, UK

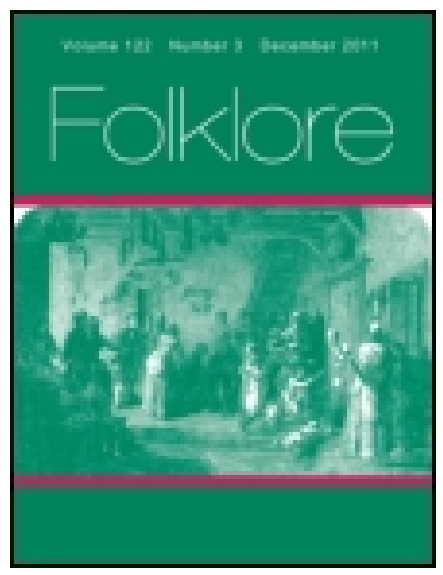

\title{
Folklore
}

Publication details, including instructions for authors and subscription information:

http:// www. tandfonline.com/loi/ rfol20

\section{Waterford Folk-Tales, II}

P. Ussher

Published online: 01 Feb 2012.

To cite this article: P. Ussher (1914) Waterford Folk-Tales, II, Folklore, 25:2, 227-242, DOI: $10.1080 / 0015587 X .1914 .9718817$

To link to this article: http:// dx. doi. org/ 10.1080/0015587X.1914.9718817

\section{PLEASE SCROLL DOWN FOR ARTICLE}

Taylor \& Francis makes every effort to ensure the accuracy of all the information (the "Content") contained in the publications on our platform. However, Taylor \& Francis, our agents, and our licensors make no representations or warranties whatsoever as to the accuracy, completeness, or suitability for any purpose of the Content. Any opinions and views expressed in this publication are the opinions and views of the authors, and are not the views of or endorsed by Taylor \& Francis. The accuracy of the Content should not be relied upon and should be independently verified with primary sources of information. Taylor and Francis shall not be liable for any losses, actions, claims, proceedings, demands, costs, expenses, damages, and other liabilities whatsoever or howsoever caused arising directly or indirectly in connection with, in relation to or arising out of the use of the Content.

This article may be used for research, teaching, and private study purposes. Any substantial or systematic reproduction, redistribution, reselling, loan, sub-licensing, systematic supply, or distribution in any form to anyone is 
expressly forbidden. Terms $\&$ Conditions of access and use can be found at http://www.tandfonline.com/page/terms-and-conditions 


\section{WATERford Folk-Tales, II.}

\section{Tim Kelly, Tom Daly, and the Spirit.}

Tim Kelly was coming one night from Dungarton at a late hour, the time that ghosts are usually out, up the glen called the Poll Cam, when he suddenly espied a ghost, ${ }^{14}$ a terrible tall one altogether, about ten feet, and says he to himself, says he,"Goodness gracious! I'm done for now; what will become of my wife and poor children ?" And only for his old mule, he couldn't get away from the ghost at all. When he was coming towards his house he had every shout, saying,- "Brighid!"15 Open the door, Brighid!" And his wife opened the door, and to her surprise in came Tim and the mule and all. And only for the wife closing the door, in was the ghost too. Tom Daly, called the "Cuinne,"18 who had been with Tim, had disappeared from Tim as the ghost came down upon him, and was found the following morning after falling over the raised path through the Poll Cam. He had smashed his braces, but otherwise he was safe and sound. He came home saying,-- "Dealing mother, I'm kilt after the night; 'tis I did see the sight, - - ghosts and spirits around me all night, screeching and bawling! Put down a kettle o' tea, and maybe it will revive me a little!"

\section{How Jim Hackelt saw a Spirit.}

One night, about 10 p.m., on my way from the glen to $m y$ employment in Bally na courty, I met a very large dog near the reservoir. I thought he was one of the neighbour's dogs, and began calling him, and, when I got close to him, the dog seemed to get a lot larger. Then I picked up a few bricks and fired them at the dog, and the dog got back to its ordinary size again. I then went down a little further, and fred stones at the dog again. The dog never stirred, and then I began to run, and lost one o' my boots before I got to Bally na courty, and tore my trousers.

11 This and the ghost in the next story are different manifestations of the spirit of a certain soldier in Cromwell's army who died in the Glen.

25 "Bridget."

${ }^{20}$ So called from his habit of sitting in the corners of cottages next to the hearth. "Cúinne" (pron. Coongey), means corner. 


\section{Petticoat-loose and the Carters.}

There was at one time at Colligan a woman who was called Petticoat-loose, ${ }^{17}$ though her real name was Mary Caine, while others say that she was called Wall. She led a very bad life, and used to be striking her father and mother, and after her death her ghost was going around killing everybody with a ton weight in the right hand with which she had been striking them.

There were two men coming up from Dungarton by the Colligan road one night, and they had a horse and cart, when one of them looked round and saw Petticoat-loose coming after them. "Oh, Dia linn anam! [O, God help us!]," said one of them. "Bheidh méd air bhthe! [We'll be killed !] Here comes Petticoatloose !" and she sat on the back of the cart. The horse could not walk with her terrible weight, for every arm of her weighed five hundredweights, and the whole of her weighed a ton. The horse sweated like a pig, and perished there on the road, and only for the men had a good song to sing for her, she would have killed them too. They kept singing till after the hour of twelve o'clock, and she disappeared then, but the men did not get over the fright till they perished.

19. How Petticoat-loose was defeated by the Scaflers.

A man was going one time to a well for a pail of water, and Petticoat-loose came down upon him. "Well," says Petti, "you won't have another minute to live in this world. Peel off all your clothes, and get into your skin." So he took off all his clothes excepting the scafflers, ${ }^{18}$ and them is what saved him. "IVell, by gar!" says the man, "for all that the King and Queen are worth, .I wouldn't take them off." "Ah, my demon," says Petti, "that's well for. ye, or I'd have ye kilt altogether." She finished then by giving him a blow, but it didn't hurt him, when he had the scafflers. Then she went off, and he went off.

\section{The Fate of Petticoat-loose.}

Petticoat-loose made her last appearance on the road to

"So called from an incident at a dance, when her petticoat fell from her on the floor.

1"Scapula. 
Lismore standing on a pier where she met three men on the road. When they were coming towards her, one said to the other,_- Dia linn anam! [God help us] we'll be kilt on the spot! That's the woman as is called Petticoat-loose," says he. "Pon my word, my three clutharacans!" says Petti, "I'll give Dia linn anam when I get down to ye!" So down she jumped off the pier. Now there were two tall men and a very small man among the three of them, and said the tall men to the small man,-- "Och, we'll save ye !" So she jumped down to them then, and, instead of saving the small man, the two tall men ran for their lives. The small man jumped then at Petticoat-loose, and caught hold of the chain that was around her waist, and drew on the chain and tightened it as hard as he could. Then he took a black-handled knife and stabbed her between the shoulders. Says Petticoat-loose to him then,-" Tarraing agus sácghadh aris" [Pull, and stab again]. "Well by gar I I wont I" says the small man, "so I'll whip ye off to the publichouse." Now the two tall men were in the publichouse before him, and the small man told the tall men to go for the clergy, or he'd let go Petticoat-loose on them. So then the priest came to the publichouse, and the minute the priest came he pulled the black-handled knife from between her shoulders, and now she had to go through an examination with the priest. Now this is her confession:-The first thing the priest asked her was what damned her? First, she said, she'd been putting water in the milk and selling it. And he said that that hadn't done it. Second, she said she had been keeping in the servants from mass on Sunday, and he said that hadn't done it. Thirdly, she said she kilt a child without it being baptized,-- "And that's what had done it." The priest then began to read over her, and, according as he was reading, she was melting; and she finished by vanishing in a cloud of fire and smoke. And at present she is in the Red Sea making sugdns [ropes] of the sand until L'an a la Brath [the Day of Judgement].

\section{The Fate of Petticoat-loose (another Version).}

There was a man as was dying, and the young man went for to fetch the priest with his horse and trap, and he met Petticoat-loose on the way to the priest's house. She left him pass all right, and 
he told the priest when he got there, and the priest asked him if he had got a candle, and he got him one. And they went along to where the young man met Petticoat-loose. And there she was again, standing among some old ruins on the side of the road. So then the young man pointed her out to the priest, and he told him to light the candle, and he took out his book and he began to read his office. Then the priest asked her what had damned her soul. And she said it was that she had took a child's life away during mass hours. Well, he there and then banished her, and she went in a flare of light into the sky, and she fell down, head downwards, and feet up, into the Red Sea.

\section{The Origin of Jacky-the-Lantern [Will-o-the-Wisp].18a}

Jacky was keeping a good life, and he had no one but his mother. And his mother died. And because he was so good to his mother, Our Lord came to him and told him he would give him three wishes, and he told him "think to himself then." Then Jacky said he had got his wishes. His first wish was that any man that should sit on a chair, he would stop in the chair till himself would be after letting him go. Now the second wish then was this :- He said that he had a garden, and that the apples were stolen from him, and he wanted that anybody who should take an apple, his hand should stick to the apple and the apple to the tree, and he should stick till he came to catch him. Well, the third wish then was this: $-\mathrm{He}$ had a pooch [purse], and anything that would go into it would stop into it till he liked to let him come out. Well then, he lived for seven years then, and then the Devil came to him-"Come on now," says he ; "come along with me." "Sit down," says Jack, says he, "till I be ready for ye." So, when Jack was ready, then says he,- "Come on, now," says he. Well, when he thought he'd get up, he couldn't get up, because he was tied to the chair. "Let me up," says the Devil, says he, "and I'll give ye seven years more till I come again." So Jacky let him go then.

Well he took great care to come for him again when the seven years was up. "Don't be making game of me now," says the Devil, says he, "Come along with me now," says he. "Och, well," says

18a Cf. W. A. Clouston, Popular Tales and Fictions, vol. i., pp. 390-5, for other versions of this story of 'The Three Wishes.' 
Jack, says he, "Come on till ye'll eat an apple," says he. So he brought him out in the garden with him. "Catch an apple," says Jack, then says he. Well, he caught an apple, and his hand tied on the apple, and the apple on the tree, and he couldn't go at all, at all. "Well, let me go," says the Devil, says he. "Let me go, and I'll give ye seven years more," says the Devil, says he. And Jack left the Devil go then.

Well, the Devil came again after the next seven years, and Jacky says to the Devil, says he, "Ye're not the Devil at all," says he ; "for if ye were the Devil," says he, "ye could make a mouse of yeerself." So the Devil did. "Well," says Jack, says he, "to show ye're the Devil jump into my purse." Then he jumped into the purse, he did, and Jack closed the purse, and went till he got three men with three big sticks, and they began to hammer the purse. Then the Devil had every screech, and he told him let him go for God's sake, and then he'd never again trouble him. So Jack let him go.

And soon after that he died, and then the Devil got hold of him, and put him back into the world as a punishment for the ways as he'd been treating him, and gave him a lantern, and told him he must be his servant in the world to be frightening and putting astray God's people.

\section{How Jacky-the-Lantern put one of God's People astray.}

Abraham Hacket was coming home late one night through Carrowgariff Reay called Reagh-na-Feadbg [pron. Ray'na Fudogé], where Jacky-the-Lantern be every night after the hour of twelve o'clock, setting people astray. Well, Abraham saw the Lantern, and he made for the light and begorra! when he went near it, it moved on farther away, and it kept moving away. And Abraham kept moving after it, and at last says to himself,- "It must be Jacky, - that's setting me astray." So he turned his coat, ${ }^{19}$ and he started to roar. And the neighbours heard him, and they found him wandering about Reagh-na-Feadog, and only for the neighbours he couldn't get home till morning, for Jacky would keep him wandering about after his Lantern all night.

${ }^{19}$ Cf. Folk-Lore, vol. xv., p. 456 (Jamaica); Mrs. Bray, Legends etc. of Devonshire, vol. i., p. 183. 


\section{The Ghost of Mr. Healy.}

There was two men went to cut down a stick [to repair a cart with] on the estate of Rochfield, and, as they got there and as they had the sticks nearly cut, the ghost of Mr. Healy, the former owner of the place, appeared on the scene on horseback, though he was never known to ride a horse during his life. Then the men got frightened, and they couldn't pull the saw for fright, and one of them fainted, and the other remained nursing him until the cock crew. Then Mr. Healy left, and they finished cutting the stick, and took it home along with them, and they had to pay very dear for that stick.

\section{The Founding of Dungarton.}

About half a mile from Gallows Hill there's a hole in a field which is the same shape as the hill, and it measures accurately the height and circumference of the hill. It is said that it was Fionn. MacCumhall that threw [the content of] this hole over which forms. Gallows Hill, and it is thought surely, without any doubt, that Dungarton is under Gallows Hill. It is supposed that, when the town of Dungarton was about to be built at this place, that they were advised to build a house near the water, and that it was better to have a town near the water than to have to carry the water to. the town.

\section{How the Clergy became Unrestful for Money.}

There was a man of a time who sold a cow at a fair to another man, and of course the man as bought the cow went home with his cow. So when he got home his wife asked him,-_"What did he give for the cow?" And so he told her. Then she told him that he had been very dishonest, and that he had cheated the man. So the other man, he went home and his wife asked him what he got for the cow. And he told her also. And she said that he'd robbed the man, and that he'd accepted too much money for the cow. So the man as bought the cow agreed to go back with a pound to the man that he bought the cow from, and the other man agreed to go back and return a pound to the other, so that each man was returning a pound. So they met half way, and each of them was trying to return a pound to the other, and either of 
them wouldn't take the pound. So they agreed to let the next man that would come up, settle the business between them. So a clergyman was the first that came that way. And the settlement that he made was that each of them should give him his pound, and he should keep the two pounds. Well St. Pádraic [Patrick] come up when the thing was settled, and he asked what was the argument about? And he was told. So he told there and then that he'd leave the unrest for the money upon the clergy from that day forward.

\section{How the Death came to Shaun MacGuire.}

My father Shaun was at Limerick one time and he met the Death. Then the Death laid alongside of him, and gave him a shake-hands. "Come and meet me at Glen Even," said the Death to Shaun, "and there make your repentance to me." "I'll not go with ye," said Shaun, "ye ugly spirit, but give me pardon for three months till I go home to Father Martin. 'Tis there ye'll find $m e$ in the publichouse among the neighbours drinking the beer, and I'll promise ye, if I get my health back again, ye won't be troubled with me again for much longer." Now this is what the Death said now,- "I brings young and old, rich and poor, and the strong men on earth." And this is what the Death said again to him,- "I am going to take ye now, I'll spare ye no longer." And he was taken away then. He was given too much for the world, and too fond of the girls, and he had to be taken away.

\section{The Sticky Spirit.20}

There was a woman lived in the neighbourhood of Colligan. She was married to an old man, and she sent the old man looking out for news every night. So one night the old man went along and met a goat boring. The man turned back then and went home again to his wife, and she asked him,--"What wonder did he see to-night?" "The goat, and he boring," answered the man. "That's no wonder," says she, and she sent him out again the next night and the goat came back the same way. The third night he

${ }^{30}$ Cf. Grimen's Household Tales (trans. M. Ilunt, 1884), vol. i., p. 274 ("The Golden Goose"). 
met the goat again. "What brings you here?" says the goat. "My. wife," said the man, "looking for wonders." "Come along," said the goat, "and I'll show her wonders enough." The goat went to their door then, and pucked at it. The servant then got up, and they had no matches in the house. The goat went in anyway, and so it must have been a spirit. And the girl put ber hand on the goat's back, and could not relieve herself. The servant boy then got up, and left his hand on the girl, and stuck on also. The old woman then got up, (as was the man's wife), and she laid her hand on the servant boy's back, feeling her way in the darkness, and stuck on again. The goat then looked at the door, and it opened, (because ye know he could not get through the door with all those people on his back).

"Have I got the lot of them now?" says the goat to the old man as was outside. "Yes, ye have," says the old man. Away with them all then, and they was after going a long way along the road when they met a man with a large shovel. Then the man gave the old woman a tip with the shovel. He was surprised, ye know, to see that great number of people, all on the back of the goat. And the shovel stuck on, and he with the shovel. Then they met a carpenter and the carpenter gave them a tip with his hammer, and he was stuck on in the same way. Then they went into a large city, and then the goat disappeared, and relieved them then.

And they all had to travel about fifty miles home and without a stitch of clothing on them.

\section{The History of Sleady Castle.}

There was a gentleman called Mr. MacGrath as lived in Mountain Castle, and in Irish he was called Soidin Pilip, as means in English Silken Philip, and he got married to one Mary Power from Curraghmore. Well, they were married for some time before he brought her to his home, and when she see the little place (as was nothing like where she came from), she wouldn't go into the house at all, for she said that her father's stables were a better residence for her. So the wedding dinner was served for them, and she wouldn't enter at all. So they went back together to Curraghmore, and he thought then that he'd build Sleady Castle for her to live in 
with him. So he commenced to build Sleady Castle then, but he was rather slow to undertake such a heavy job, for he thoughthad he means enough to build it? So all the MacGrath family, priests and all, came to help Philip, and the building went on grand. Well, they were after working at it for seven years. Then it was finished, and the MacGraths came to live in it. But MacGrath died after the seven years of building, and so he never came to live in it. Well Mrs. MacGrath had four childer,-three girls and a boy; but the son died in a short time after. So there was only the widow and the three daughters left then. Well, the daughters used to visit Clonmel occasionally, and they got to be friendly with three young officers there, for Clonmel used to be a great place for sodgers at the time. So they asked their mother's leave for to give a party at the Castle for these officers, and she gave them the leave. Well, there was a noted robber in the vicinity who was for a long time wishful to come to Sleady Castle to rob it, and the robber's name was Green. So he found out that these officers were coming, and it was a grand opportunity for him. Now this robber had two servants, (and I suppose the servants were as good as the master). So one of the servants got friendly with one of the servant girls in the Castle. So she promised him that she'd get the key of the drawbridge, if possible, on the day the party was held, for ye know the Castle was surrounded with water. So she told him how she'd give the signal if she'd got the key. And this was the signal :-There was a small window in the top o' the Castle, and she'd put a blue light in the window if she had the key, and they'd be well able to see the light in their cave. So the officers came, and their servants, and there was a great blow up at the Castle. Now Mrs. MacGrath was never known to let the key of the drawbridge out of her hands from the time that her husband died till then. But she left the key in the kitchen this night by mistake. Well, Mrs. MacGrath's and the officers' servants were enjoying themselves in the kitchen, but they were not content with their enjoyment, but they wanted to bring the officers' servants to the publichouse near at hand. So they went off, and then the girl went and gave her signal with the blue light; and Green and his men came then, and they had no difficulty in getting in. They popped upstairs to the diningroom 
then, where Mrs. MacGrath and the guests were enjoying themselves, and of course they got a divilish fright when they see the three men coming in and they not expecting any danger. The officers at any rate jumped to their feet for to make a struggle. But the robbers drew their blunderbusses, and told them sit tight and quiet where they were or they'd fire at them. So they took the three officers and tied them up, and then was the time to plunder the house. So Mrs. MacGrath asked Green not to be letting his men to be interfering with her daughters. So Green granted her request, and told around that any of his men as would interfere with Mrs. MacGrath's daughters he would shoot him. They went and plundered the house then, and took everything, gold and silver and everything that was of value in the house, they took it away with them. So, when they were after removing the things across the drawbridge, they came back for the officers, but Mrs. MacGrath stood up again, and she said she was asking another request, - not to interfere with the gentlemen but to leave them where they were. But Green said he had granted her one request, and he wouldn't grant her another. So they marched away with the officers. And there was not another word heard about them for three months afterwards. Now the girl as had had the wickedness to betray her mistress was taken by sorrow for having done this wicked thing, and she went away from the place and wandered about, pining and regretting till she died. And the place where she died is called Kilbrine, and it means the church of drops.

Well, in twelve months after there was a man looking for a herd of cattle, as was after straying away from him, and when he went into a certain glen near Druid Mount, what should he see but the three sodgers in the stream as was running through the glen, and they had been drowned by the robbers. And their belts and their buckles, (for they were in uniform), were shining there in the water and that stream is called "The Sodgers' Ford" from that day to this after these three unfortunate gentlemen. Well, when the report was given, the authorities from Clonmel came to fetch them and bury them, and it was thought that there had been a plot laid by the MacGraths to kill the sodgers. So they were took from their lands and their house, and they had to live in a small 
house beside the road, and they were very poor people entirely. Well, there was a gentleman living at Cappagh Castle at that time, and his name was Osborne, and he was wanting a wife. So he thought that it would be a great honour to get one of the MacGraths, although they were so poor. So he rode up to Mrs. MacGrath's house one morning, and rapped at the door. So Mrs. MacGrath came out and welcomed him, and she asked him in. But he said he would not come in until he knew would he get what he wanted, and that was her eldest daughter's hand in marriage. So of course Mrs. MacGrath was glad to have a rich gentleman coming after her daughter, and so she approved readily. So she called out her eldest daughter, and she refused to marry him, and she said she was too poor to marry a rich gentleman, and that it would not be proper for her to marry anybody after the man who would have been her husband had been killed. So the second daughter was brought, and she refused him too on the same account; also on account that the Osborne blood hadn't been long enough in the country. And the third one then came, and her name was Deas Mãrin Soidin Pilip, which means in English "Sweet Mary Silken Philip," because ye know "Silken Philip' was her father's name. Well, she accepted him, and they married and lived for a long time at Cappagh Castle, and she was very charitable and good to the poor.

\section{Fiann MacCumhall and Saint Pódraic.21}

Fionn MacCumhall was travelling of a day, and he heard some noises in a lios 22 by the side of the road, and he got down off his horse. Well, there was a small stream flowing round the lios, and a woman washing clothes by it; so he spoke to the woman, and was making love with her.' And she told him to come across the stream to her. And when he did come across, the stream appeared to him to be a very large river entirely, and he couldn't be coming back over it. So he had to remain there, and he was three hundred years awaiting there in the lios with the fairies. But he enjoyed himself so well there that he did not feel the time,

${ }^{21}$ Cf. supra, p. I11, 11. 8-9, as regards the probable origin of this story (of which the latter part is usually told about Oisin).

${ }^{2} \mathrm{~A}$ green mound supposed to be a dweling-place of the fairies. 
and it only seemed like a pair of years to him. And there was no change in him from the day he went in there, and he was quite as young as the day he had come into the lios.

Well, when he thought he had been two years there, he got anxious to see his people, and asked for to go home for to see them. So they told him that there was no one belonging to him or any trace of anybody who knew him left in the world. However, he would not be satisfied, and they had to let him go. So they gave him a pony to ride upon, and told him not to come off it, or to be letting his feet touch the ground, because, if he did, he'd be an old man again.

Well; he was coming along then near to where he had lived before, and everything was changed, and he was that surprised at it all that he was near falling off his pony. Well, he met a man on the road who was on horseback and he with a bag of wheat on his back, and the bag suddenly fell off the man's back, and he was all legs struggling to get the thing on his back again. So Fionn MacCumhall asked him was he the sort of man as was in the country now? And the man said,- "Yes, of course. What other class of men would be in the country at all?" Then Fionn asked the man to put the bag standing on end in the road in the place where it was after falling, and it was the reason that he told him,-that he might catch hold of it and give it to the other man on the horse's back. So he did. And Fionn caught the bag, and was throwing it on to the other man's horse so that he could catch it. But he threw it too far, and threw it over the horse altogether. He got vexed and excited then, and forgot himself entirely. So he came off his pony then, and went on the ground, and he became a withered old man on the ground there and then. So the pony (as was a fairy pony) ran away from him, and ran straight back, to the lios where he was after coming from.

Well, Fionn was travelling about for after a week, -a poor feeble old man, - when he met Saint Pádraic. And Saint Pádraic questioned him, and he told him his tale and what was after happening to him.: So Saint Pádraic took him home with him, and kept him in his house and fed him. But himself and Saint Pádraic and Saint Pádraic's housekeeper could never agree at all. And the housekeeper wouldn't be giving him enough to eat, for 
there was no mistake but Fionn could eat like a giant,-for what else was he? Well, ye wouldn't think he had much to complain about, as he got a leg of mutton every day for his dinner. But he was always telling the housekeeper that in his time the leg of a blackbird was the size of one of her legs of mutton. "Well," saidshe, "you lie," says she. Well, he made no remark, but he thought it was a terrible insult altogether. But he said he'd prove it to her, and that he'd get her the blackbird's leg as was bigger than her leg of mutton. Well, he had a great difficulty in doing this, for he had to get a dog and rear this dog himself, and it couldn't be any ordinary dog. So, as Saint Pádraic had a hound as was goin' to have pups, (and they were the first litter of pups she'd had), he told Saint Pádraic to watch and to be sure to get bim the first pup as should be born. But she had already pupped, and the pups were mixed, so that he could not get the first pup at all, at all. So Fionn got a sheepskin, and nailed it against a door with the fleshy side out. Well, Fionn was blind at the time. So he told Saint Pádraic's boy to take one of the pups and to throw it against the skin. Then he asked Saint Pádraic's boy, did the pup fall? He said "yes." So he told him to throw all the pups one by one against the skin. So the last pup stuck to the skin, and Fionn asked him,- "Did he stick to the skin?" "Oh yes," says Saint Pádraic's boy, "he's after sticking to the skin." "Well, drown all the rest of the pups," says Fionn, "but keep him," says he. So this pup was called Bran. Well, he reared up Bran for twelve months, and, when the twelve months was over, he thought Bran was able to do his work. Now, there was a big trumpet that had belonged to those giants ${ }^{23}$ which had been hidden by Fionn MacCumhall in his young days. And this trumpet could summon all the birds in the world to him. So himself and Saint Pádraic's boy went for the trumpet, and they stood on the hill of Teamhair (Tara) and sounded the trumpet. Then he told the boy to watch and to have Bran in readiness. And he said to the boy,- "There's one big bird," says he, "that'll devour us all," says he, "only that we have Bran," says he, and it's for that he had Bran. Then he told the boy to look out and

23 The Fianna. It is the common idea among the peasantry that Fionn and his Fianna were of gigantic size. 
to tell him what was coming, because himself couldn't see at all, ye know. So the boy said he saw the sky dark with birds coming from all directions. Then he asked him, did he "see any remarkable bird a coming?" says he. "Well," says the boy, "there's one bird coming," says he, "that looks as if it could cover a field, so it might," says he. "It's a terrible big bird entirely," says he. "Well, when that bird is perched on the ground," says Fionn, "we're done for if Bran don't be able for him." So the bird came then, and Bran and the bird had a great battle. And Bran at last killed the bird. So Fionn caught one of the legs of the bird, and brought it home to Saint Pádraic's housekeeper, and he asked her, "Is that," says he, "not bigger than three of your legs of mutton?" says he. "It is," says she. "Well, do you remember," says he, "when ye told me," says he, "that I was a liar?" says he. "I do," says she. Then he took the leg of mutton and smashed her across the brain with it, and that done for her. "Ye'll never again," says he, "tell anybody that lie," says he. So Saint Pádraic came on the scene then, and he was in an awful state entirely. And he asked Fionn MacCumhall what was this he had done? So Fionn explained the matter to Saint Pádraic and told him the reason, and Saint Pádraic was satisfied with him then.

Well, Saint Pádraic kept him then for a long time trying to make him a Christian, (for ye know he had always up to this time been a dirty Pagan); and he succeeded in the end, but it wasn't an easy thing for him. Well, he consented then to be baptized, and, when Saint Pádraic was baptizing him, he wasn't very sure of his faith, for he thought he was only lukewarm, ye know. So, to test his faith, he took hold of a little short spear he had in his hand, and let it drop on Fionn MacCumhall's foot. Now Fionn MacCumhall was bare footed at the time, and he was not wearing boots on him. And so he began to bleed. So Saint Pádraic pretended that it was accidental, and said he was sorry. So Fionn MacCumball answered, and said,- "Don't it belong to the baptism?" said he. So Saint Pádraic had tested him then, so he was satisfied with his faith when he was willing to be bleeding for his faith. So for the rest of his life Fionn MacCumball remained a good Christian. 


\section{I. The Ghost of the Blacks.}

One night, about eleven years ago, when I was a child, I was coming from a dance at about II.30 p.m., and I said to myself, says I,- "Begorra! I won't be frightened at all; the night is so bright, and I have such a short way to go." When I came into the three-cornered field called the Blacks, by the jigs and reels, what should I see but a big tall spirit. He was eleven feet tall and about seven feet wide, and he was trotting along behind o' me. Now my hair was hanging, and what should he do but stick out his paws, (for he looked like a big tall dog; his teeth were two inches long, for upon my soul! I could see them all in the moonlight) on my back, making grasps at my hair. And begorra! I thought he'd eat me altogether, and as I ran he was trying to be grasping at me, and as I reached the door $o^{\prime}$ my house I thought I'd never get inside with the fright o' him. But faix then! It didn't take me long to get in and to clap the door out after me, and away with me upstairs to bed, and every drop o' sweat on me as big as a wren's egg! But never a wink could I sleep that night, and the fright $o^{\prime}$ it was in my heart after three months.

\section{The Combating of the Giants.}

There were four brothers living in Modelligo called the Fitzgeralds, as was terrible powerful men and was giants, and there were four brothers (as was also giants) and who came from Tipperary, and thought themselves as good a men as they, and maybe better. So they came to the house to see which was the strongest set of men. . But they found no one there but the housekeeper. So they turned away all the Fitzgeraids' cattle off their land, and were taking them home with them, so the Fitzgeralds coming home caught them taking away their cattle. So the battle began there and then between them, and it was a terrible sight to see. So the four Tipperary brothers were killed in the battle, and three of the Fitzgeralds, So one of the Fitzgeralds lived to come into his house, and the housekeeper asked him when he came in what happened to him. So he told the housekeeper all that happened, and so the story became known, for there was no other account of the battle given, for there was no one to witness the 
battle and the other young men were all killed. Then he told her "give him a drink," and that then he would die, and she could have the place then all to herself. Then he drunk her cup o' tea, and died directly after it. Well, there was a large horse-shoe found on their land about fifty-three years ago, and its circle was as big as a soup plate, and it weighed seven lbs. It was supposed to be the shoe of a terrible big horse altogether that had belonged to one $o$ ' these Fitzgerald brothers.

P. Ussher.

\section{JeRSEY FolkLore Notes. ${ }^{1}$}

THE Jersey country houses of the seventeenth century were thatched with straw, and a stone staircase was, generally, approached from the outside; these stone staircases, in some instances, continued to exist until lately. The interior of the house comprised the kitchen or hall with its big chimney, its settle, its "lit de'veille," its wooden benches, and its shelf under the low rafters where the bacon was suspended, and the loaves of bread arranged. There was, too, the dresser, where were displayed the wooden platters, crockery, and pewter plates, jugs, and dishes. The windows were not glazed, but latticed, or had a cloth stretched over them by day, and were closed by a shutter at night. The great hall of the house was called the "salle"; another apartment was added, originally, it is supposed, to monasteries; it was a little room for the reception of visitors, and known as the "parloir"; these rooms were still in use some forty years ago.

As late as the year 1824 the old farmers were frequently met with wearing their large cocked hats and their "queue a la française," and, amongst the females, the short jacket or bed gown and coarse. red petticoat formed a prevalent, but declining,

1 Many items in these notes have been previously and frequently recorded for the larger British Isles and elsewhere, but they are retained here because of the lack hitherto of any substantial account of the folklore of Jersey.-ED. 